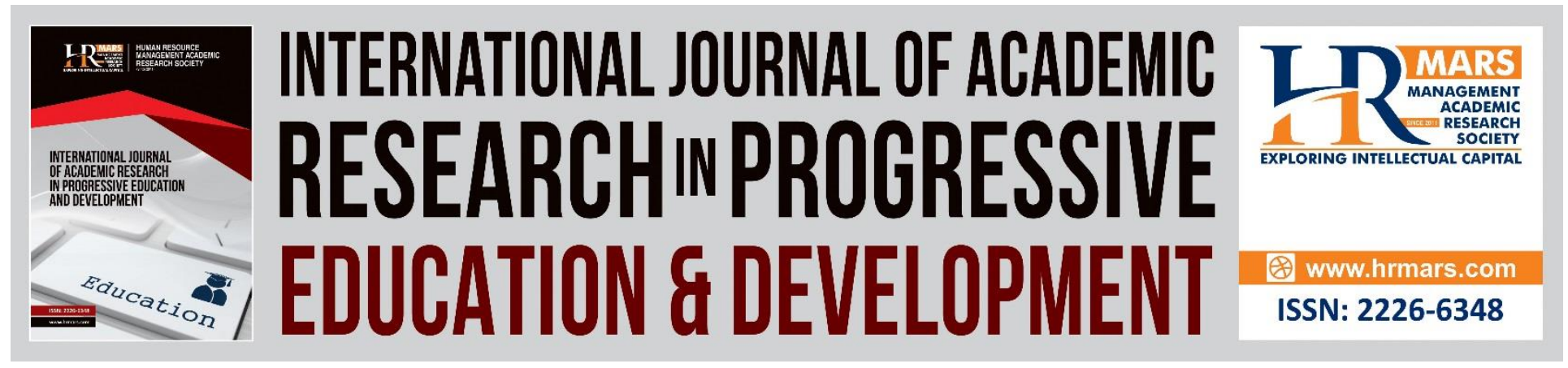

\title{
Influence of Different Learning Environments in the Implementation of Technical Vocational Education and Training policy in Nigeria
}

Muhammad Abdullahi, Nooraini Othman

To Link this Article: http://dx.doi.org/10.6007/IJARPED/v10-i2/10028

DOI:10.6007/IJARPED/v10-i2/10028

Received: 04 April 2021, Revised: 05 May 2021, Accepted: 25 May 2021

Published Online: 14 June 2021

In-Text Citation: (Abdullahi \& Othman, 2021)

To Cite this Article: Abdullahi, M., \& Othman, N. (2021). Influence of Different Learning Environments in the Implementation of Technical Vocational Education and Training policy in Nigeria. International Journal of Academic Research in Progressive Education and Development, 10(2), 687-702.

Copyright: (C) 2021 The Author(s)

Published by Human Resource Management Academic Research Society (www.hrmars.com)

This article is published under the Creative Commons Attribution (CC BY 4.0) license. Anyone may reproduce, distribute, translate and create derivative works of this article (for both commercial and non-commercial purposes), subject to full attribution to the original publication and authors. The full terms of this license may be seen at: http://creativecommons.org/licences/by/4.0/legalcode

Vol. 10(2) 2021, Pg. 687 - 702

http://hrmars.com/index.php/pages/detail/IJARPED JOURNAL HOMEPAGE

Full Terms \& Conditions of access and use can be found at http://hrmars.com/index.php/pages/detail/publication-ethics 


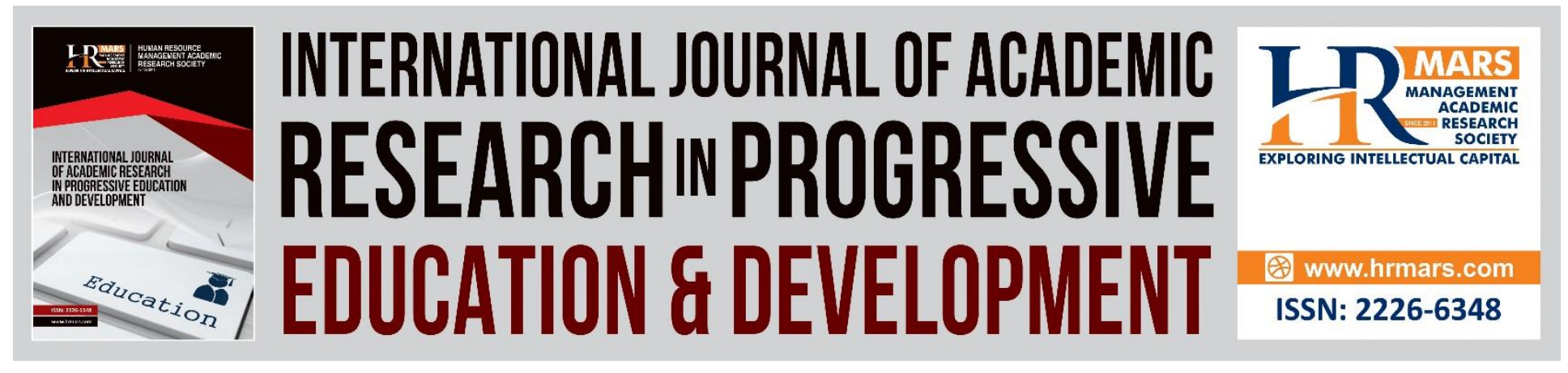

\title{
Influence of Different Learning Environments in the Implementation of Technical Vocational Education and Training policy in Nigeria
}

\author{
Muhammad Abdullahi, Nooraini Othman \\ Perdana Centre of Science Technology and Innovation Policy, Razak Faculty of Technology and \\ Informatics Universiti Teknologi Malaysia, Kuala Lumpur, 54100, Malaysia \\ Email: saboaudu76@gmail.com
}

\begin{abstract}
Technical vocational education and training (TVET) are seen as an important tool in economic growth and poverty reduction in many developing countries. There is evidence that creating a work environment and duplicating the industries equipment in the TVET institutions is costly and pushed the budget high and cannot be afforded by the government. This lead to vocational education to be done in an academic setting, working on fictional tasks that are not in line with daily real work tasks. Although the influence of the learning environment on TVET policy implementation has been reported, little is known on the perspective of school leaders in the use of different learning environments. The study aims to understand the combination of different types of learning and learning environments influence the implementation of TVET policy. The study is based on a semi-structured qualitative interview with nine school leaders in TVET institutions in Nigeria. The study used thematic analysis to analyze the data and NVIVO qualitative data analysis software to organize the data. The paper and pencil coding method was also used for the analysis. The study finds out that combining different types of learning and learning environment may contribute to the effective implementation of TVET policy and increase the employability of TVET graduates. From the perspective of the school leaders combining different types of learning and learning environments will facilitate job-ready graduates. The results of the study should be used to guide the implementation of TVET policy and facilitate the combination of learning environments.
\end{abstract}

Keywords: Learning Environments, Implementation, Technical Vocational Education and Training, Policy, Nigeria

\section{Introduction}

Technical Vocational Education and Training (TVET) has become a critical sector in the nation's economic development in many countries in the world after many years of neglect. With the 
worsening youth unemployment crisis, the world is facing. TVET in many developing countries is regarded as a critical element in economic growth and poverty reduction. Therefore, as we enter the Industrial Revolution (IR 4.0) era, it has become essential to train our students in technical skills to implement, improve, and evaluate national economic growth and development. TVET is one of the educational sectors in which professional jobs are created and will lead to the country's development in the Industrial Revolution (IR 4.0) and be successful internationally. While the emphasis on higher skills grows dramatically and their critical position on the new knowledge-based market, TVET reflects on the capacity to provide young people with a chance to take advantage of current job prospects, which affects global poverty. Students and Parents prefer the academic University route to that of the TVET apprenticeship route programs. Given the unemployment rate of TVET graduates in Nigeria and the formal sectors' capacity to employ the graduates, self-employment through dual TVET has become a viable option (Ministry of human resources, 2013). It has been recorded that a lot of students on an internship in many countries end up being employed after the internship program.

TVET believes to be an education for those incapable of pursuing an academic program against this background TVET is made to progress slowly. Hassan (2015) indicated that Nigeria's TVET system does not seem to achieve its national goals and objectives. The policy does not match the curriculum implementation processes towards self-employment and national development. Moses (2016) observed that the principal problems face by technical vocational education and training in Nigeria are the absence of sufficient funding, lack of materials and outdated facilities, lack of training programs for teachers, lack of institutional structure, and the requisite educational support materials. The lack of links between TVET institutions and enterprises, stigmatization of TVET students (Moses, 2016). These problems are not peculiar to Nigeria only, but they are in almost all the developing countries. Consequently, these problems and other external factors have led to the collapse or decline in education quality and particularly TVET.

TVET in Nigeria occurs at the vocational schools that are often done in an academic setting, working on fictional tasks that are not in line with real work tasks daily. Pinnow (2019) stated that this creates problems when students graduate since they lack the practical skills and knowledge needed to fulfill job requirements. Furthermore, there is evidence suggesting that creating a work environment and duplicating the industries equipment in the TVET institutions is costly and pushed the budget high and cannot be afforded by the government (Ministry of human resources, 2013). There is growing concern about the employability of TVET graduates (Idris \& Mbudai, 2017), The study aim at understanding the influence of combining different learning environment in the implementation of TVET policy in Nigeria. The dual TVET theory of combining different learning environments or the interlinking of learning at the workplace and theoretical reflection (Sp and Schulte, 2019), which will nurture job-ready TVET graduates guide the study.

\section{The Objective of the Study}

The objective of the study was to understand the combination of different types of learning and learning environment influence on the implementation of TVET policy, the challenges in using different learning environments, and to identify how to scale-up the implementation of 
Vol. 10, No. 2, 2021, E-ISSN: $2226-6348$ @ 2021 HRMARS

TVET policy. The results of the study will improve the implementation of the TVET policy of nurturing job-ready graduates.

\section{Theoretical Framework}

Technical Vocational Education and Training (TVET) programs are mandated to nurture students with specific skills, knowledge, and practice to be job-ready upon graduation. This demand the need for TVET to combine different learning environment to achieve employability of TVET graduates. Sp \& Schulte, (2019) conceptual model for interlinking learning at the workplace and theoretical reflection or dual TVET is the theoretical framework of this study. To cope with unemployment challenges due to continuous change in the employment situation, the faster rate of technological change in high-tech sectors, and ongoing enhancement of the work quality, there is the need for a combined different learning environment. Source (Sp \& Schulte, 2019). The combination of two learning venues in TVET has the advantage of nurturing job-ready graduates; this will improve the attractiveness of TVET in general and enhance employer engagement since TVET can be responsive and adapts to the industry's needs.

The theory combines different types of learning and learning environments to nurture jobready graduates. The model strengthens the cooperation between TVET institutions and employers, which is term as a dual TVET system and enables the implementation of combining learning and practice, which will benefit the learners and employers and facilitate students' school-to-work transitions. The theory indicates that skilled workers' training requires combining different types of vocational learning and selected learning environments. The theory takes place in the institutional setting, while practice in the workplace. The dual TVET system's main feature is the linking of learning at the workplace and theoretical reflection. A systemization of learning content and a close alignment of options for the different learning environment is necessary (Sp $\&$ Schulte, 2019). The theory will guide the coding and data analysis process.

\section{Table 1 combining different types of learning and learning environment}

\begin{tabular}{|c|c|}
\hline Type of Learning & Learning Environment \\
\hline Abstract learning & Classroom \\
\hline Learning structured-Content & Laboratory \\
\hline Demonstration and Action & \\
\hline Learning Basic Skills & School Workshop \\
\hline $\begin{array}{l}\text { Learning Complex Skills ( with expensive } \\
\text { equipment) }\end{array}$ & Central learning facility \\
\hline $\begin{array}{l}\text { Learning Basic/ more Complex Skills (with } \\
\text { expensive equipment) }\end{array}$ & Training Facility/Training Corner at Workshop \\
\hline $\begin{array}{l}\text { Learning appropriate skills in a real work } \\
\text { environment }\end{array}$ & Workshop \\
\hline
\end{tabular}

Source (Sp \& Schulte, 2019)

\section{Method}

The study conducted semi-structured qualitative interviews with school leaders (rectors, provosts, head of departments, unit heads, and teachers) who implement TVET policy in their 
institutions (Polytechnics, Monotechnics and Technical Colleges) in Nigeria. Interview questions were design example "how the combination of the different learning environment in your institution and workplace influence the implementation of TVET policy? what are the challenges in using the different environments in your institution? And how to scale up the implementation of TVET policy. The questions were all reviewed to determine their relevance to the objective of the study, the interview questions were structured within the maximum time limit of 30-40 minutes.

\section{Participants Recruitment}

Participants were recruited purposely who are school leaders involved in the implementation of TVET policy in Nigeria, snowball sampling was also used to ask the initial participant to recommend who to interview next. Based on the principle of saturation sample size was not determined. The interview process will continue as long as new themes emerged. The research uses pseudonyms to identify the interview participants' three-letter pseudonym for each participant who disguises the gender with no relation to the study and has no reference of the participant's name and maintains anonymity assured in the interview process. The transcription and coding process began immediately once the participants returned the transcript via email. This helped to bring up early findings and then shape subsequent interviews and guide the data collection early. The coding process and theme construction were slowly showcasing a saturation point at the seventh interview transcript. Furthermore, two additional interviews were conducted, and the researcher felt sure that the information was saturated then the interview process of the study was concluded. All the participating school leaders sign the consent form and provided verbal consent to the audio recording of the interview.

\section{Data Collection}

The interview was conducted online due to the COVID 19 lockdown. The online interview cannot completely replace the face-to-face interview, as Lo-lacono Valeria, Symonds Paul, \& David H K (2016) stated. The online interview also works well as an essential alternative or complementary data collection for qualitative research. Nine interviews were conducted, of which three were face to face, three by skype, and the other three by WhatsApp call. Skype. WhatsApp call and voice recorder allow the interviewer to record the video conversation. The interview was transcribed verbatim and email to the participants for their reading. Suggested changes to the transcript by participants were verified with the audio recording. If the verifications were accurate, changes were made to the transcript. If the suggested changes are new information that the participants wish to add that are not recorded in the audio, are tagged post-interview information in the transcript with the symbols' <. > and the text will be in an italic font, which is considered as post transcript details.

\section{Data Analysis}

The study transforms an interview into written form and determines how the interview data will be analyzed. The thematic analysis was selected to allow the researcher to review the facts more 
carefully and put together points of view from various stakeholders on the research emphasis. The study data analysis utilized the NVIVO 12 qualitative data analysis software to organize the data. The paper and pencil coding method was also used for the analysis. The study adopted Braun, V \& Clarke, (2013) seven thematic analysis stages (TA). 1) Transcripts 2) Reading and familiarization, note-taking of items of potential interest 3) Coding Complete throughout all the datasets 4) Themes Searching 5) Themes reviewing (producing thematic map). 6) Defining themes and naming them 7) Writing and finalizing Analysis.

\section{Result}

The participants' school leaders interviewed agreed that there is a need to combine different learning and learning environment. Classrooms and other institutional settings in the TVET institution side and additional learning environment at the industry side to produce job-ready graduates who can be employed or be self-employed. The study elaborates the different learning with four sub-themes which are.

(1) Combining different learning and learning environment

(2) Industries

(3) TVET Institutions

(4) Challenges in using a different environment

(5) Scale-up of TVET policy implementation

Combining different types of learnings and learning environments

The analysis also focuses on the combination of different learning and learning environment. The learning environment used in the industry setting as identified by participants interviewed is work-based learning or industrial attachment or internship as it is referred to at the TVET institutions. while classroom, laboratory, and school workshop are identified as a learning environment in the TVET institutions. The nature of TVET education applied study and its policy to graduates students who are work-ready enable it to adopt pedagogical approaches that replicate the industry practices (Narayananayar, 2017). All the interviewed are familiar and use to combine different types of learning and learning environments in their institution; as stated by a participant.

we use to combine different kinds of learning and learning environments for the students as the practical aspect of their courses. We have all the learning environment, and we are using them. We have workshops; we have laboratories, we have a farm and orchard.

All the participants believe that this learning environment can support learning and practice to facilitate learners' transition from school to work. As they states that

Combining the two environments will help the students, and it will assist them a lot because we gain a lot of experience by making use of these facilities.

A participant expresses this as follows 
we combine different learning and learning environments. This is part of the training in the TVET institutions we use. We have laboratories, classrooms, lecture theatres, and all those we have them and our students are exposed to different learning environments.

Participants generally have a different perspective on the essential skills and knowledge that all TVET graduates should possess that will enable them to secure a job or be self-employed after graduation they are (1) skills required by the industries (2) information communication technology skill (3) production skill all the three are mentioned by two participants each while (4) practical and current knowledge (5) entrepreneurship skill (6) Technical Vocational Education and Training are mentioned by one interviewee each. As presented by a partiipant, for instance, TVET students need entrepreneurship skills apart from the technical skills that will assist them in selling their technical skills.

The skills you know differ from area to area field of work, so for every work may be Mechanical Engineering have different skills with electrical engineering or building. But what is the essential skills all TVET graduates most have is entrepreneurship skills that will enable them to be selfreliance because if they have the technical skills already, they know how to fabricate, how to do that, but they need to know how to sell that their technical skills to the market they need entrepreneurship skills.

A participant emphasizes vocational education, industrial attachment, and entrepreneurship education programs as the essential skills and knowledge that all TVET students will possess to secure a job or be self-reliant, as he said.

Industries

Participants indicated that theoretical courses are being tough in the TVET institution while practical are conducted in the workplace industry through the Industrial Attachment scheme. Participants identify learning in the real work environment in the industry as the commonly used learning in the workplace setting. Workplace learning provides the TVET student with workrelated learning as explain by a participant.

If the students were posted to the right industry and the right department based on his area of study he will acquire the requisite work experience but if the student is not posted to the right industry and department base on his study the student will not learn anything.

Industries are seen by participants as a key stakeholder in the implementation of TVET policy they employ the students and can advise on what is lacking from the TVET graduates. The participants state that an industrial-based supervisor who represents the industry can clearly state what is lacking from the students attached under his supervision in terms of skills and knowledge and is left for the TVET institutions to address the concern. As expressed

The Industrial Attachment links the institution-based supervisor [representative of the TVET institution] with an industrial-based supervisor [representative of the 
industry] to assess the students. The assessment will be based on comments made by an industrial-based supervisor for example if he said the student is not coming to the workplace or not performing tasks assign to him the student has to repeat the attachment.

Work-based learning

Learning based on work or industrial attachment or internship as it is referred to in the TVET institutions prepare the students for the industry, work-based learning or industrial attachment or student internship program (SIP) focuses on delivering meaningful work experience for final year TVET graduates. Students are attached to an industry and work tasks are specifically given that are aligned with the abilities in which they are trained. Normally, industry attachment learners act as full-time employees of the company and follow all the procedures of the organization. Other than the need to keep a reflective log of their learning, the students have little interaction with the faculty members. Institution-based supervisors act as a liaison officer between the organization of the workplace and the TVET institutions to keep an eye on learners learning from a distance.

The institution-based supervisor gets involved by visiting the workplace organization to observe the student performing tasks at the workplace and to see if there is a misalignment of the student task and knowledge, and to check the logbook of students learning. Students are required to work as full-fledged workers within the company because this is TVET part of the nurturing process of job-ready graduates. It is expected that students learning from the Industrial Attachment or Student Internship Program would cultivate and shaped their skills in technical, social, and communication. Besides, the program also offers employers the opportunity to assess the students' employability. Participant shares his view on work-based learning.

Work-based learning is important because without the industrial attachment program the students will not know how the real work environment looks like. The students will think that everything is theoretical but the real work environment is not theoretical is practical.

There is a need to prepare students for learning in the workplace. Participants suggested the extension of the internship duration from 12 or 16 weeks to 24 or 30 weeks. This will provide the TVET students with authentic work experience and exposed them to the industry as stated

The government. should try to look at the duration of time students spend in their internship program with the industry, I think the time is not sufficient for the students, I think the government. should increase the time limit for the internship maybe you can make an internship for the whole year for example that one I think is better instead of just spending 3 months for an internship, 3 months is not enough for the students to get a reasonable experience from the industry where the student is attached.

TVET Institutions 
TVET institutions are those institutions that are under the supervision of the National Technical Education Board they are Polytechnic, Monotechnic, Technical Colleges, etc. they are saddle with the responsibility for nurturing job-ready graduates who can be employed or be self-employed after graduation. Participants mention the following types of learning and learning environment that take place in the TVET institutions.

\section{Classroom}

Participants recognize the need for the classroom for learning abstract information which is referred to as theoretical reflection that takes place in the classroom settings. All participants' interviewees use the classroom as a teaching environment and stated that students spend most of their time in the classroom environment. Therefore, the classroom environment is very important in the transition of students from school to work. As expressed by a participant

The classroom as a teaching environment must be conducive for the students. We are all in the business because the students and everything in the institution should cater to their needs including the classroom.

The classroom environment should be conducive for the students to be attentive to the teacher and respond to his questions. Participants believe that for a well-functioning classroom the teacher needs to consistently make an effort to create and maintain conditions that will foster teaching and learning in the classroom effectively. As explain

A classroom as a learning environment should be well organized and managed, wellfurnished, and equipped, free movement of students around the room. This will facilitate a conducive environment for teaching and learning and transition from school to work.

And

The classroom as a teaching environment depends on many interactions among teachers to students and students to students.

\section{Laboratories}

The laboratory enables the students to learn structured content through demonstration and action (Sp \& Schulte, 2019). A laboratory is a learning environment where students work individually or in a group to solve a problem. Participants explain the importance of laboratory in the TVET institutions as stated

I cannot imagine in the TVET Institutions students do not work in the laboratory. In the laboratory, the students do something from there they understand what the teachers have been telling them in the classroom.

School leaders interviewed reported that there are many benefits to using the laboratory as a learning environment in the TVET institutions in Nigeria. A laboratory is a unique learning and teaching environment in which students can cooperate and work in a small group to investigate scientific phenomena. As stated 
Vol. 10, No. 2, 2021, E-ISSN: 2226-6348 @ 2021 HRMARS

The laboratory allows the students to work in a small group and may enable the students to collaborate and assist one another.

And

Laboratory environment enables the students to connect theoretical knowledge to the application

\section{School Workshop}

The next category develops under the theme TVET institution is the school workshop. Participants believe that school workshops will enhance students learning and will mold them to be job-ready after graduation. It will allow students to quickly experience the real work environment. School workshops engage the students in learning basic and complex skills and keep them active. As explains

In my institution, there are school workshop to introduce the students to a more authentic environment so the students will know what the real work environment is within their school setting

School workshops provide the TVET students with a real-life task but done within the border of the TVET institution. A stated as a teacher in the government technical college, I make sure that students learn in the school workshop which is a realistic and safe environment.

School workshop is seen by participants as a training ground for the students before they embark on industrial attachment. School workshops provide students with a secure place to learn skills and to be closely watched by the teachers as well. The TVET institution needs to partner with the industry to make the students better in the area of skills development. The interviewees indicated the usefulness of involving the industry in the evaluation of a project done by the students in the school workshop. This will provide students with real-life experience in conjunction with members of the industry.

The industry-based supervisor is involved in evaluating the student project conducted in the school workshop. The industry comes to the TVET institution and we find out there is value in that.

We do have a partnership with industries they come to our institution and they give comments on students' work conducted at the school workshop.

Challenges in using a different environment

Participant school leaders identify the following categories as challenges in using different learning environments in nurturing job-ready graduates they are

(1) Admitting un-qualified students

(2) Carrying capacity

(3) Collaboration between TVET and Industry

(4) Equipment and facilities 
Admitting un-qualified students

Participants feel that majority of the students admitted in TVET institutions are un-qualified because of the perception that general academic education is favored in Nigeria the brilliant students go to academic education while TVET is seen as the second option and is for lower achievers. Brown et al. (2011) classify children with the intellectual ability to receive an expanded education while lower labor force levels are those with low academic knowledge and the factory model. TVET in Nigeria is recognized by many as low-status education and for the less privileged. This leads to admitting unqualified students. Unfortunately, some students accepted in the TVET institutions are not qualified to be admitted because they did not possess the requirement to be taken this is a major challenge as express by a partiiapant

The challenge is the suitability of the students; the criteria of taking the students also from the management sometimes use to admit students that have not possess the requirements to be accepted they do not have the requirement to be admitted, so in that situation when you admitted someone that does not have the requirement some of the students try to cope with the situation while some of them will not.

\section{Carrying Capacity}

The students who have been admitted are more than the facilities available. The government gives more attention to academic education and neglecting Vocational and Technical Education in Nigeria. Evidence shows there is a lack of equipment in the TVET institutions in Nigeria, and where they are available, they are overcrowded. The students only watch the instructor carrying out the practical, which they cannot replicate due to lack of equipment availability. As explained

The challenges are the carrying capacity, for instance, workshops, laboratories. The numerical students to the facilities are not commensurate with the numerical strength of the students the facilities are there but they are not enough that is the idea. Electricity challenges in an open problem in Nigeria.

And

One of the challenges we face every day is the number of students being admitted; the number is always too high; maybe you have a class of 200-300 students. Hence, I think it isn't easy to manage 200 students to participate in the practical aspect.

Collaboration between TVET and Industries

Participants indicated that the TVET education in Nigeria is provided at the TVET institutions, which are often done in an academic setting, working on fictional tasks that are not in line with real work tasks done on a routine basis. This creates problems when students graduate since they lack the practical skills and knowledge needed to fulfill job requirements (Pinnow, 2019). The only collaboration between TVET and the industry is through the industrial attachment scheme

The industrial attachment provides the synergy in which TVET institutions can collaborate with the industry. Industrial Attachment enables the institution to understand industry 
requirements likewise the industries would know what skills and knowledge the institutions are imparting to their students. Collaboration between TVET institutions with industries has an extremely powerful impact on the quality of learners. The common collaboration that existed was industrial attachment or internship placement among others (Moses, Muladi, \& Wibawa, 2017). This is shared by a participant as follows

Yes of course there is collaboration between the TVET institutions and industries that already exist in Nigeria. The Industrial Training Fund (ITF) is a government regulatory agency and it is the one that is bridging the relationships enable the collaboration between industries and institutions when it comes to the issue of Industrial Attachment.

Equipment and Facilities

Participants mention that equipment and facilities are not enough in the TVET institutions. Therefore, duplicating and re-creating the equipment in the industry to the TVET institutions is costly and the government cannot afford it. This lead to the establishment of the industrial attachment program which will enable the TVET students to gain first-hand knowledge of the day-to-day operations in the industries. Therefore, TVET in Nigeria is done in an academic setting providing theory in the classroom, this will create a problem because the students lack practical skills and knowledge of the workplace. As shared by a participant

There is hindrance coming from the availability of equipment, machines, that will help students in being employed or job-ready.

Scale-up of TVET Policy Implementation

Participants suggest that funding, support and collaboration between TVET and industry will scale-up the implementation of TVET policy. Particiapants believes that to improve and scale-up TVET policy implementation, there is a need for collaboration between TVET institutions and the industries. As narrated

Agreement or collaboration with the industry enables the students to quickly get employment if they acquire the knowledge required or technical skills. Suppose there is no agreement from the institution with the industries. Graduates will face a difficult time getting to the stage of being employed.

Paticipants suggests that to improve and scale up the implementation of TVET policy, we need amenities that include raw materials and consumables for practical. In contrast, participant indicates that the implementation of TVET policy will be improved when there is support by the heads and enough funding and collaboration with all stakeholders at the institutions and industries, so there must be a collaboration.

Almost all the participants indicated that they are not aware of any general guidelines or policy implementation indicators in their institution. This is iterated by a participant as follows. 
As of now, I don't know of any guidelines. So if someone can come up with a guideline that is a contribution to academia, it will be something new. As of now, I don't know; this is one of the things we are lacking. If you can have such a guide model or framework, it will be a welcome development to our TVET program.

Some participants' school leaders, feel that TVET policy implementation achieves its purpose, and it is above average.

It is achievable. To some extent, we are making progress towards that direction because now students are aware they need to engage in skills apart from theoretical knowledge they get in classrooms; they also need to engage in entrepreneurship skills before graduation. So it helps them a lot to be job-ready and to be self-employed and self-reliant.

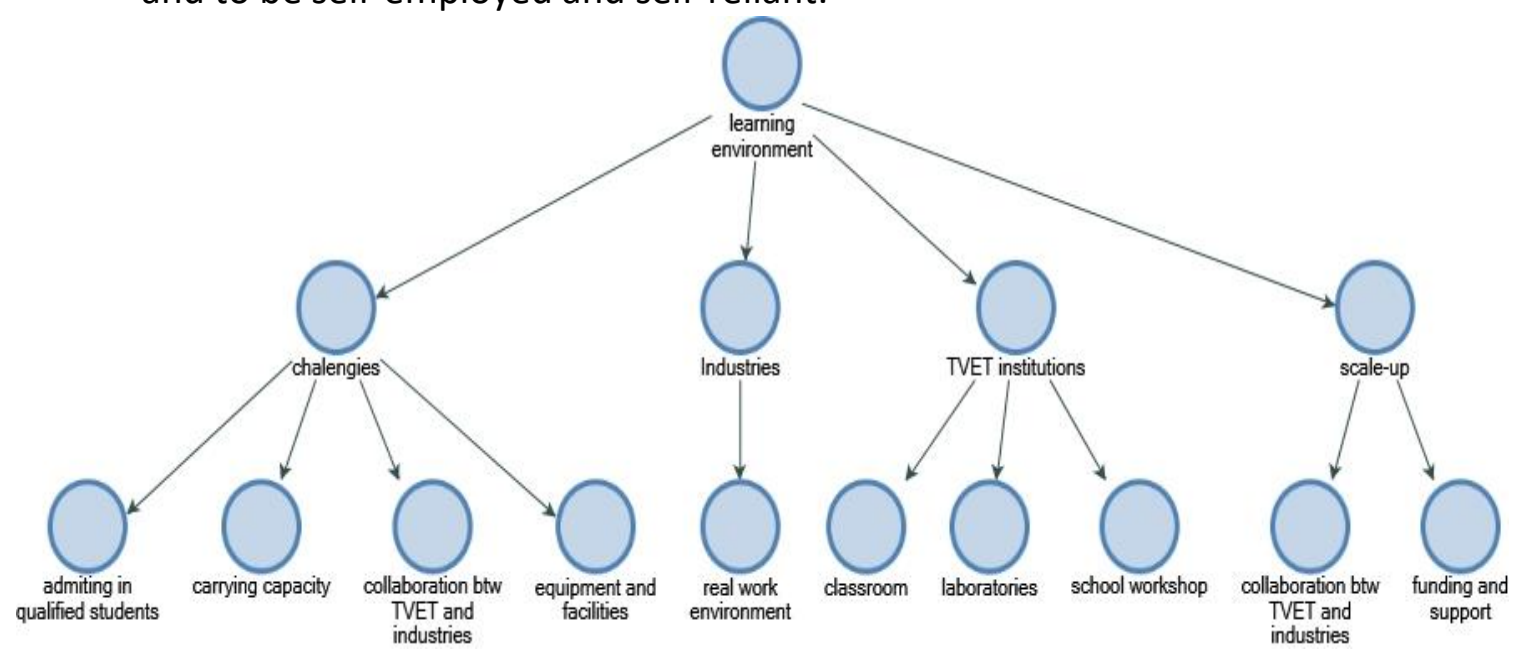

Figure 1 Learning Environment Supports the Implementation of TVET Policy

Figure 1 Participants' school leaders supported the need to combine different learning and learning environments in TVET institutions. The four themes and sub-themes discussed to analyze the learning environment in the TVET institution are classrooms, laboratories, and school workshops. At the same time, industries provide a real work environment. Another theme is the challenge face by TVET institutions in the use of a learning environment. Participants identify carrying capacity, a collaboration between TVET institutions and industries, lack of equipment and facilities. Participants identify how to scale-up the implementation of TVET policy collaboration with industries, support from stakeholders, and financial resource availability.

\section{Discussion}

Results indicate that the learning environment supports TVET policy implementation, and there is a need to combine different types of learning and the learning environments. The dual TVET supports this abstract learning at the TVET institutions and real work environments at the industries (Chen, 2019; Pinnow, 2019; Sari, Idris, Latifah, \& Ariffin, 2019; Sp \& Schulte, 2019). However, the study result indicated that the TVET institutions in Nigeria mostly provide theories in their institutions' settings, which is a fictional task and are not in line with a real work situation 
in the industries. This creates problems when the student goes for an industrial attachment in the company; they lack the practical knowledge and skills required to fulfill the job requirements. The literature supports the statement (Pinnow, 2019). The transition from school to work can be more comfortable when two different learning environments are combined. Some practical skills and knowledge can be learned in the school workshop and make the TVET student job-ready. This will make the TVET institutions attractive and enhance employer engagement since it is responsive and adapts to the industry's needs. The interview data also shows that the workplace learning is more suitable than school based practical learning due to resource restriction

The study found that there are challenges in using different learning and learning environments to nurture job-ready graduates. The first challenge is the carrying capacity of the number of students been admitted in the TVET institutions is too high compare to the facilities available. Second, the collaboration between TVET institutions and industries is fragile because the industries are not enough to absorb the students. Sometimes, the students find themselves in irrelevant industries that are not related to their area of study. Third, lack of equipment and facilities in the TVET institutions, and the government are not ready to increase the budget due to economic recession. Creating a work environment and duplicating the industries equipment in the TVET institutions is costly and pushed the budget high and cannot be afforded by the government (Ministry of human resources, 2013). The interview data also revealed that to scale up the implementation of TVET policy, collaboration with industries and TVET should be based on demand, not supply, and the need for a shared understanding of TVET policy documents and stakeholders' support, financial resources availability. The analysis has revealed the need to combine different types of learning and the learning environment which will enhance TVET policy implementation are the identified area for change. The results of the study indicated a need for the combination of types of learning and learning environments, which will lead to the implementation of TVET policy by school leaders and may contribute to effective implementation and ultimately lead to TVET graduates' employability

\section{Conclusion}

The Technical Vocational Education and Training in Nigeria focuses on nurturing job-ready graduates with knowledge and skills upon graduation. However, the lack of cooperation between TVET institution and industries that will enable the combination of different types of learning and learning environment. The combination of learning environment is a share responsibility between stakeholders in the implementation of TVET policy in Nigria. The combining of different learning environment will promotes partnerships between TVET institutions and industries to reduce the unemployment rate caused by the job-skill mismatch. Studies indicated that combining learning environment will promotes cooperation between TVET and industry, resulting in high employment rates (Dernbach, 2020). The study recommends the need for learning in an authentic work environment where a student will work on a realistic day-to-day task. Therefore, only technical and vocational know-how, entrepreneurship education, learn in the TVET institutions, and work-based learning in the industries will prepare the students for actual work tasks that will make them employable after graduation. It is also recommended that TVET institutions combine learning in the school environment and work-based learning, nurturing job-ready graduates. 


\section{Limitation of Study}

The study has several limitations with regards to the school leaders selected as participants may not be representative of the larger pool of school leaders in the TVET institutions across Nigeria. The sample size of nine participants school leaders is too small but qualitative study is about indepth rather than breadth. The study also did not interview TVET students, parents, and industry stakeholders. Therefore, the study is not fully aware of their concern and thoughts about combining different learning environments in the implementation of TVET policy in Nigeria. Students, parents, and the industries may have a different perspective on the learning environments To understand the combination of different types of learning and learning environment influence on the implementation of TVET policy would involve the interviewing of school leaders (Principals, Rectors, provost, Head of departments, Unit head, and teachers) of TVET institutions, and the students, parents, and industries in Nigeria to explore their perception on the combination of different types of learning and learning environment influence on the implementation of TVET policy This study had focused only on identifying the school leaders' understanding on the influence of combining of different types of learning and learning environment on the implementation of TVET policy in Nigeria. Future research is needed to explore the perspective of other stakeholders in the use of different learning environments in the implementation of TVET policy.

\section{Conclusion}

The study analyzes the research question of how different types of learning and learning environments influence the implementation of TVET policy in Nigeria. The study discusses the participants' voices and followed with a project map done through the Nvivo 12 software to visualize the themes and sub-themes' presentation. This finds out that combining different types of learning and learning environments will enhance the implementation of TVET policy in Nigeria. There are several challenges in using different learning environment result indicated that admitting un-qualified students, carrying capacity, a collaboration between TVET and industry, equipment, and facilities are the main challenge facing TVET institutions in the combination of the different learning environment. Funding, support, and collaboration between TVET and industry will scale-up the implementation of TVET policy. Combining different types of learning

and learning environment may contribute to the effective implementation of TVET policy and increase the employability of TVET graduates.

\section{References}

Braun, V., \& Clarke, V. (2015). Successful Qualitative Research a practical guide for beginners. Retrieved from https://books.google.co.uk/books?hl=en\&lr=\&id=nYMQAgAAQBAJ\&oi=fnd\&pg=PP2\&dq=B raun, $+\mathrm{V}+$ and+Clark, $+\mathrm{V} .+2013$.+Successful+qualitative+research.+A+practical+guide+for+be ginners.+London, + SAGE+publications.+\&ots=SpMywcCYay\&sig=Ggno62TBxtRj5kZQcOEDIJjmK0\%0Ahttps:/

Chen, L. U. I. (2019). Editorial TVET @ Asia Issue 13 : Dual TVET systems, Employer Engagement and Modern Apprenticeship Schemes. Tvet Online Asia, (13), 1-3.

Dernbach, A. (2020). Philippine Experience in Dual Training System. In Education in the Asia- 
Pacific Region (Vol. 55, pp. 101-108). https://doi.org/10.1007/978-981-15-7018-6_13

Hassan, H. H. (2015). Vocational and Technical Education: A Tool for Sustainable Development in Nigeria. Journal of Education and Practice, 4(25), 127-131.

Idris, A., \& Mbudai, Y. (2017). Technical and vocational education: Challenges towards youths empowerment in Kano state-Nigeria. Journal of Technical Education and Training, 9(1), 112. Retrieved from https://www.scopus.com/inward/record.uri?eid=2-s2.085021295043\&partnerID=40\&md5=504ce65c8851858f1d722a4a26e19109

Moses, M. K., Muladi, M., \& Wibawa, P. A. (2017). The Linkage between Vocational High School Cooperation with Industries in field of Information Technology in Malang. Proceedings of the 1st International Conference on Vocational Education And Training (ICOVET 2017), 116(Icovet), 12-15. https://doi.org/10.2991/icovet-17.2017.3

Ministry of human resources. (2013). Sudan TVET Policy. Retrieved from http://www.ilo.org/wcmsp5/groups/public/@africa/@ro-addis_ababa/@srocairo/documents/publication/wcms_243649.pdf

Moses, K. M. (2016). Improving the quality and competence of technical vocational education and training output through vocational school cooperation with industry: A case study of Uganda. AIP Conference Proceedings, 1778(2016). https://doi.org/10.1063/1.4965794

Narayananayar, V. s/o. (2017). Politechnic education in Singapore: An exploration of pedagogies for a polytechnic. University of Sheffield.

Pinnow, S. (2019). The German Dual VET System and Approaches to enhance Employer Engagement. Tvet-Online .Asia, (13), 1-18.

Sari, N. M., Idris, S., Latifah, \&, \& Ariffin, M. (2019). The Potential of Dual TVET System Players in Co-curricular Activities-an Approach from Malaysia. Tvet-Online .Asia, (13), 1-14. Retrieved from www.tvet-online.asia

Sp, G., \& Schulte, S. (2019). The Dual System in Germany - Is it prepared for Digitalization. Www.Tvet-Online.Asia, (13), 1-16. 